\title{
Meet the 2018-19 APSA RBSI Scholars
}

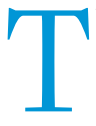
he Ralph Bunche Summer Institute (RBSI) is an annual five-week program designed to introduce undergraduate students from under represented racial/ethnic groups or students interested in broadening participation in political science and pursuing scholarship on issues affecting under-represented groups to the world of graduate study and to encourage application to $\mathrm{PhD}$ programs. This is the 32 nd year of RBSI excellence! The 2018 RBSI program, held at Duke University, ran May 27-June 28, 2018.

\section{Deja Bryant}

Deja is an honors student at Howard University, majoring in political science and minoring in journalism. Deja is an Artishia and Frederick Jordan Scholar as well as a Reginald F. Lewis Scholar at the university. Passionate about activism, Deja is serving her second term as the vice president of Howard University's NAACP chapter and works to mobilize disenfranchised communities through political and civic engagement. She also serves as the secretary for the Howard University Political Science

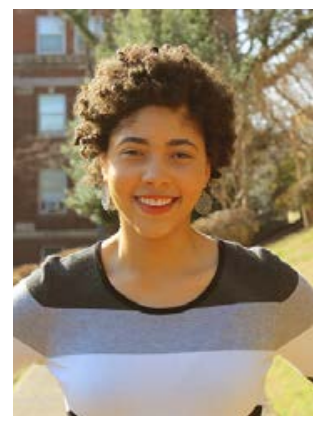

Society. Deja's dedication to social justice, people, and politics is reflected in her various research experiences. She has worked as a researcher for the Digital Ward Valley project focusing on the activism of Native American tribes in Ward Valley, California; and as a policy and programs intern at the Public School Forum of North Carolina. She has explored racial equity at the intersection of education, government, and advocacy; and worked as a researcher for the Congressional Black Caucus Foundation Avoice Virtual Library. Deja is currently conducting her undergraduate honors thesis research on partisanship as it relates to political behavior within the black electorate. Deja aspires to advance her education by entering into a dual JD/ $\mathrm{PhD}$ program and embarking on a career that embodies equity, equality, and giving voice to disenfranchised groups.

\section{Michelle Henderson}

Michelle is a student at New York University majoring in politics and minor-

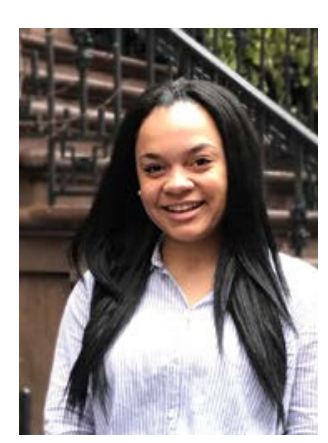
ing in linguistics. Michelle is an AmeriCorps member and team leader with Jumpstart, and is involved on campus with the Academic Achievement Program, the Organization of Black Women, and the NYU Politics Society. She has received scholarships through Americans Promoting Study Abroad and the Chinese Summer Language, Culture and Technology Initiative (CSLCT-I) which have allowed her to study Mandarin and clean energy in Beijing and Hangzhou, China. Michelle has presented her research in the Pomona College Chinese Department, and has translated United States citizenship application information into Mandarin through Scripps College in Claremont, California. Upon graduation, Michelle plans to return to China before coming back to the United States to pursue graduate study in international education policy and international human rights.

\section{Alfredo Y. Hernandez}

Alfredo is an honors student at Loyola Marymount University (LMU), majoring in political science with a minor in economics. A McNair Scholar, his research centers on how political theory can be harnessed to measure and inform local governments' obligations to their minority constituents and what constitutes their ethical governance. At LMU, he is the editor in chief of Attic Salt, an interdisciplinary academic journal which services all 28 Association of Jesuit Colleges and Universities campus-

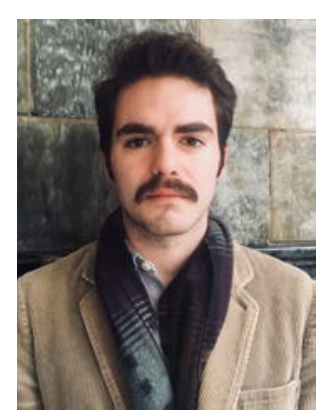
es. He is also an active member of the MAGIS Service Organization, which works to address homelessness in Los Angeles by serving in homeless shelters and working with at-risk youth; Pi Sigma Alpha; and Alpha Sigma Nu. During the summer of his freshman year, Alfredo received an Honors Summer Research Fellowship to study how the Greek government has utilized cultural centers to combat their recession post-2008 crisis-sparking his interest in researching abroad. He has also participated in the Hansard Scholars program, interning with the Offices of Alex Norris, MP in Parliament, while also studying at the London School of Economics. For that program, he wrote a dissertation on utilizing demographic data to predict MP rebellion. As a child of Mexican immigrants and a first-generation college student, he looks to become a professor of political theory and inspire more diverse voices to enter the field. He also hopes to be involved in local politics in his home city of Los Angeles.

\section{Michael Herndon}

Michael is a rising senior and first-generation Chicano college student at the University of Nebraska, Omaha (UNO). Michael is double majoring in political science and international affairs with a minor in ChicanoLatino Studies. A UNO Regents Scholar and honors student, Michael just completed a spring internship with Rep. Norma Torres (D-CA) on Capitol Hill through the Congressional Hispanic Caucus Institute. Michael has also interned with the development team of the National Immigration Forum's DC office. At UNO, Michael is involved with various cultural organizations. He has previously served as the president of UNO's Multicultural Greek Council; has held various leadership positions within the Delta Beta Chapter of Sigma Lambda Beta International Fraternity Inc;

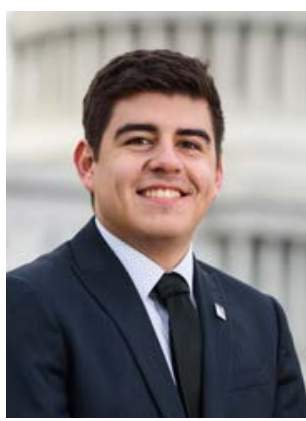
and is an active member of UNO's Association of Latin American Students. Michael's passion for Latin America runs deep and led him to do a summer abroad in Costa Rica to refine his Spanish language skills. Michael has won department-wide scholarships in both the UNO political science and international studies departments and has been accepted into the $4^{+1}$ Political 
Science Program at UNO. This program will allow him to take political science graduate courses as an undergraduate in order to get a head start on his MS in political science. Michael has aspirations to get a second master's degree or $\mathrm{PhD}$ after graduating. $\mathrm{He}$ plans to pursue a career in diplomacy.

\section{Aayana Ingram}

Aayana is a rising senior at Alabama A\&M University. A Dean's Scholar, her research interests focus on African American politics, ethics, and the political attitudes of black students at Historically Black College and Universities (HBCUs) compared to those

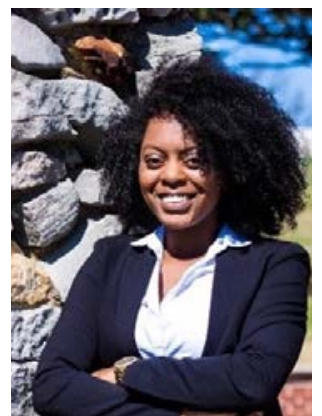
who attend predominately white institutions (PWI). Last summer, for the second time in a row, Aayana had the opportunity to intern with the Department of Energy conducting research on bioenergy sustainability. She presented her research at the Southern Political Science Association (SPSA) conference in New Orleans, Louisiana. Aayana is heavily involved on campus as a member of the honors program, Miss Omega Psi Phi, and as the junior class senator in the Student Government Association. She uses these platforms to advocate for her student body on issues that are plaguing their institution. As a product of a historically black college, upon graduation Aayana hopes to earn a doctoral degree in political science, teach on the collegiate level and mentor young African American men and women.

\section{Flavio Jimenez}

Flavio is a junior attending San Francisco State University, majoring in political science and minoring in classical archaeology. Flavio was raised by politically active parents from El Salvador, who have been supportive of his desire to become a political activist. Born and raised in San Francisco, Flavio

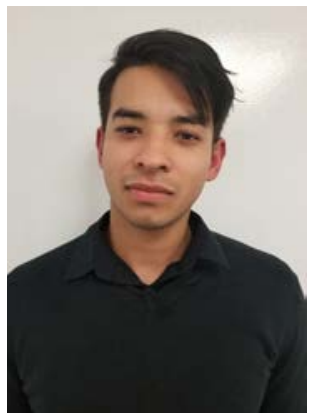

has been involved with various local organizations including the Japanese National
Honors Society, Meritus, and Minds Matter San Francisco. Flavio has been actively involved within the community in order to help the residents of San Francisco. Along with volunteering for these organizations, Flavio has also had the opportunity to intern for the incumbent mayor of San Francisco, Mark Farrell. These experience have all contributed to the development of Flavio's aspirations in becoming a United Nations Ambassador. Through the Ralph Bunche Summer institute, he hopes to gain knowledge and analytical skills that will allow him to succeed in a graduate political science program.

\section{Isaiah C. Johnson}

Isaiah is a rising senior political science major at the University of Houston. A member of the Honors College and a Dean's List recipient, his research interests focus on

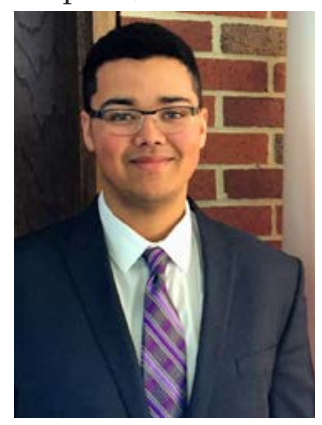
understanding the evolution of parties on issues like immigration, social policy, foreign policy, and exploring the conditions under which bipartisanship and compromise occur. Isaiah is also interested in exploring the influence that the executive has on the legislative and judicial branches of government. During the 2017-2018 academic year, Isaiah had the privilege of working with Dr. Jennifer Clark at the University of Houston on research exploring the interaction between the president and Congress on immigration measures. He has a good deal of experience within the field of political science, having worked as an intern at a congressional district office; holding the financial chair position for Pi Sigma Alpha; as well as holding the communications chair position for the University of Houston College Democrats. In the future, he hopes to earn a doctoral degree in political science and teach students at the collegiate level.

\section{Jasmine B. King}

Jasmine is a junior at Jackson State University majoring in political science. Since her freshman year, Jasmine has conducted research under the direction of Dr. Byron Orey. Though the research that she participates in addresses the psycho-physiological reactions of African Americans in response to police violence, her current research interests focus on the effects of race, gen-

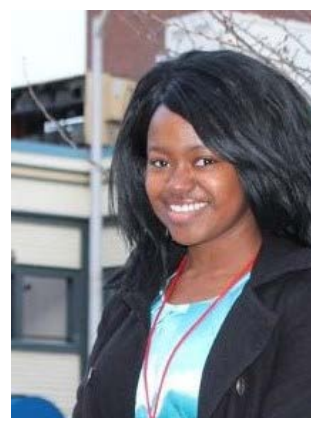
der, and class inequalities on political behavior. Having a good deal of experience in research, Jasmine has presented research at conferences such as the Pi Sigma Alpha Undergraduate Student Research Conference and the Emerging Researchers National Conference. Jasmine plans to enter a dual degree program to earn a juris doctorate and a doctoral degree in political science.

\section{Leann Mclaren}

Leann is a political science and history double major at the University of Connecticut, in the honors program. She serves as the vice president of the University of Connect-

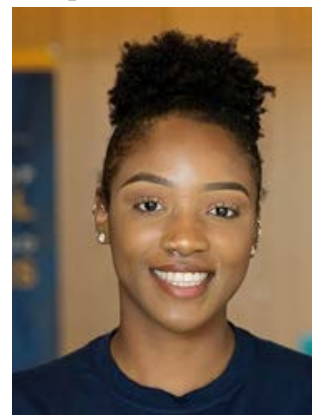
icut's chapter of the NAACP, as well as on the College of Liberal Arts and Sciences Leadership Board. A Dean's List and New England Scholar, her research interests center on the effects of racial bias in congressional legislative proceedings and how this may affect policymaking. Over the course of her undergraduate career, Leann has been able to accumulate a good deal of research experience, as she has assisted on several projects facilitated by university faculty, including homicide and sex trafficking on women of color, gender bias in congressional hearings, and archival research on Caribbean immigration. She also has had many internship experiences, including at the University of Maine School of Law's Pre-law Undergraduate Scholars Program, and her current role as a congressional intern in the United States House of Representatives, in the office of Congressman John B. Larson. Leann also has a passion for volunteer work as she has been on several alternative break service trips, including to Birmingham, Alabama, and at Right2know, a civil rights organization, as a part of her study abroad trip to Cape Town, South Africa. Leann hopes to 
receive a doctoral degree in political science and teach at the university level.

\section{Geidy Mendez}

Geidy attends the School of Arts and Sciences/Douglass Residential College at Rutgers University and is a double major in

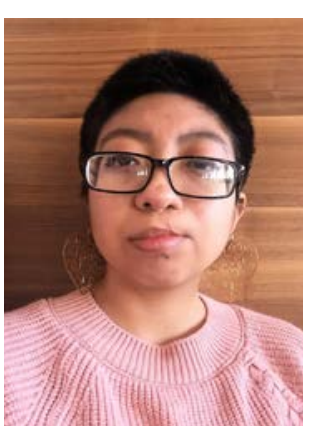

political science and Latino \& Caribbean studies. She is a 2017 intern and work study student for the Center for American Women and Politics and is actively involved in various organizations around campus such as the Latin American Women Organization, G.O.Y.A. (Galvanizing and Organizing Youth Activism), and the First Generation Student Union. In addition, she is the Class of 2019 Representative for the Douglass Governing Council. She has interned at El Centro Hispano Americano where she worked on domestic abuse cases for undocumented individuals ensuring that they are heard regardless of their immigration status. She hopes to pursue graduate study and focus on immigration patterns that affect minority communities.

\section{Crystal Robertson}

Crystal is a rising senior political science major at the University of Michigan. Her research interests focus on racially centered

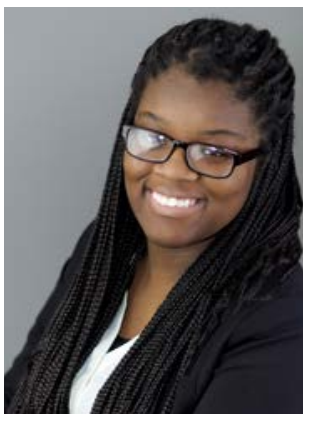
activism and white allies, specifically the motivations of white allies in racefocused social movements. Last summer, Crystal had the privilege of working under Dr. Mara Ostfeld and Nicole Yadon investigating the relationship between skin color and political preferences. She currently serves the Michigan Research Community as a residential advisor supporting first- and second-year students pursuing research opportunities. In the future she hopes to earn a doctoral degree in political science and continue encouraging students to pursue research as a professor.

\section{Vanessa A. Navarro Rodriguez}

Vanessa is a senior studying government at Cornell University and is interested in

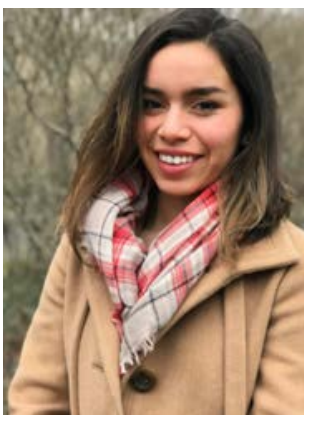

American politics and its effects on marginalized communities. She has spent over two years working with Dr. Jamila Michener, in Cornell's government department, on various projects like researching federal laws regarding civil legal aid and conducting a policy analysis for the city of St. Petersburg, Florida. Following her research on civil legal aid, Vanessa spent a semester in Washington DC, interning in the government relations department of the Legal Services Corporation, a congressionally funded nonprofit. During this time Vanessa worked on the budget request for fiscal year 2019 and also drafted memos on the importance of civil legal aid. Vanessa plans to write her senior thesis on sexual violence in universities and the role of race in the outcome of the accusations. Aside from her research experience, she also serves on Cornell's Presidential Task Force, where she is contributing to creating a more inclusive and diverse institution. Vanessa aspires to become a scholar and understand the limits and functions of the law in protecting marginalized populations in the United States.

\section{Analisa I. Quintero}

Analisa is a rising senior, international affairs major, and Spanish language minor

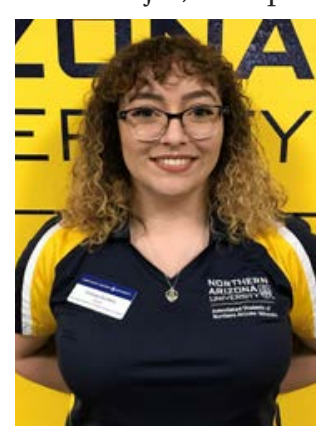
at Northern Arizona University. As a student recognized by her college's Dean's List every semester of her college career, she has focused much of her time working to provide resources and representation on campus for underrepresented groups of people. Analisa currently serves as a senator for Associated Students of Northern Arizona University for the College of Engineering, Forestry, and Natural Sciences. Analisa is the founder and president of NAU's Spanish Language Club, as well as the executive board secretary for Alpha Lambda Delta Honor Society's NAU chapter. She is a resident assistant on campus and works to help freshman students acclimate to college life, get involved at school, and in the Flagstaff, Arizona community. After graduation, Analisa hopes to earn a doctoral degree in political science and serve in public office.

\section{Michael Strawbridge}

Michael Strawbridge is a junior at Beloit College double majoring in political science and media studies. Michael currently serves as the vice president of the Alpha Zeta chapter of the Sigma Chi fraternity and as vice president of the Student Athletic Adviso-

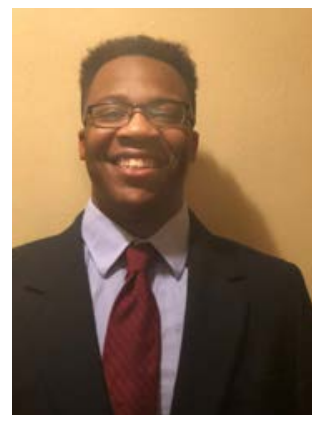
ry Committee. His other activities include being on the football team and track and field team. As a McNair scholar, he researched the progress made in Ferguson, MO since 2014, assessing the city's progress and challenges in enacting reforms moving forward. Michael's research interests include American politics, elections, criminal justice, and police reform. Once he completes his undergraduate studies, Michael plans to pursue a doctoral degree in political science and teach at the collegiate level. Aside from teaching Michael also plans to run for office.

\section{Catalina Udani}

Catalina is an honors junior at the University of Central Florida studying human communication, intelligence and national security, and terrorism studies. She has received the Lawrence J. Chastang Global Fellowship and the India Fellowship for Political

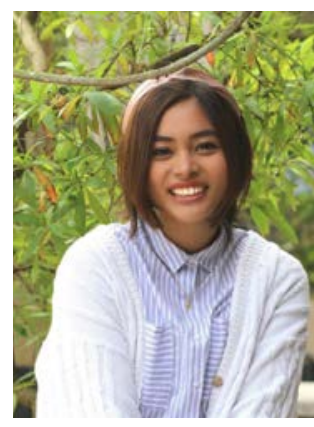
Science Research, working with the Global Perspectives Office at UCF specializing on international conflict communication. A Dean's List and National Merit scholar, she recently completed her undergraduate honors thesis, which was a thematic analysis of digital ISIS propaganda, framed with theories of communication. One of five 
members of her university's Ethics Team, which placed fifth in the National Intercollegiate Ethics Bowl, Catalina developed research interests in political ethics, public relations, and justice through mediation. She spent last summer working in Munich, Germany in international public relations as a translator and a bilingual writer. After immigrating to the United States as a child, Catalina became interested in the ways emergent media could affect international communication, particularly in the amelioration of conflicts in foreign relations. Upon graduation, she plans to use her research interest to pursue a graduate degree in peace and conflict studies.

\section{Zoe Walker}

Zoe is a junior at the University of Notre Dame studying English and political science. Passionate about both research and community involvement, Zoe has devoted her time at Notre Dame to pursuing both service and academics. She has served as an intake volunteer at Indiana Legal Services

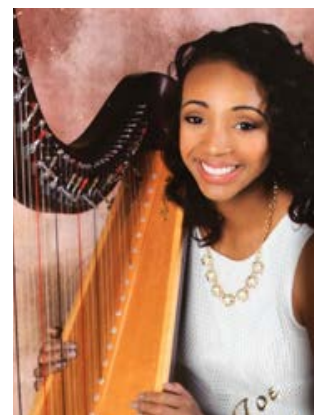
in South Bend, Indiana; worked as an intern for a public defender in St. Joseph County and has worked for the Northern Indiana Reentry and Restorative Justice Clinic, a nonprofit organization that helps former offenders to expunge their criminal records. Zoe's real-life experiences have shaped her interest in academic research. Inspired by her time working with both the legal aid clinic and the public defender, Zoe pursued research on the importance of considering intersectionality in family court proceedings and the vulnerabilities black women face in the family court system. For both this work and her high academic standing, she was named as one of Notre Dame's Doan's Scholars and was selected to present her research at Notre Dame's Undergraduate Scholars Conference. Zoe has also worked as a research assistant for Dr. Traci Burch at the American Bar Foundation where she analyzed local newspaper coverage of police brutality, fatal police encounters, and subsequent protests. As a writer, Zoe also enjoys working with her peers as a tutor in the university Writing Center and as an editor for her university's undergraduate political science journal Beyond Politics. She looks forward to pursuing a joint $\mathrm{JD} / \mathrm{PhD}$ program to unite her interests in the relationships between communities and legal systems and the politics that drive the construction of these systems. 